\title{
Gasoline prices and their relationship to drunk-driving crashes
}

\author{
Guangqing Chi ${ }^{\mathrm{a}, \mathrm{b}, *}$, Xuan Zhou $^{\mathrm{a}, \mathrm{b}}$, Timothy E. McClure ${ }^{\mathrm{a}, \mathrm{b}}$, Paul A. Gilbert ${ }^{\mathrm{a}}$, Arthur G. Cosby ${ }^{\mathrm{b}}$, \\ Li Zhang $^{\mathrm{c}}$, Angela A. Robertson ${ }^{\mathrm{b}}$, David Levinson ${ }^{\mathrm{d}}$ \\ a Department of Sociology, Mississippi State University, PO Box C, Mississippi State, MS 39762, USA \\ b Social Science Research Center, Mississippi State University, PO Box 5287, Mississippi State, MS 39762, USA \\ ${ }^{c}$ Department of Civil and Environmental Engineering, Mississippi State University, PO Box 9546, Mississippi State, MS 39762, USA \\ d Department of Civil Engineering, University of Minnesota, 500 Pillsbury Drive SE, Minneapolis, MN 55455, USA
}

\section{A R T I C L E I N F O}

\section{Article history}

Received 17 May 2010

Received in revised form 28 July 2010

Accepted 13 August 2010

\section{Keywords:}

Drunk-driving crashes

Gasoline prices

Alcohol consumption

Mississippi

\begin{abstract}
A B S T R A C T
This study investigates the relationship between changing gasoline prices and drunk-driving crashes. Specifically, we examine the effects of gasoline prices on drunk-driving crashes in Mississippi by several crash types and demographic groups at the monthly level from 2004 to 2008, a period experiencing great fluctuation in gasoline prices. An exploratory visualization by graphs shows that higher gasoline prices are generally associated with fewer drunk-driving crashes. Higher gasoline prices depress drunkdriving crashes among young and adult drivers, among male and female drivers, and among white and black drivers. Results from negative binomial regression models show that when gas prices are higher there are fewer drunk-driving crashes, particularly among property-damage-only crashes. When alcohol consumption levels are higher, there are more drunk-driving crashes, particularly fatal and injury crashes. The effects of gasoline prices and alcohol consumption are stronger on drunk-driving crashes than on all crashes. The findings do not vary much across different demographic groups. Overall, gasoline prices have greater effects on less severe crashes and alcohol consumption has greater effects on more severe crashes.
\end{abstract}

(c) 2010 Elsevier Ltd. All rights reserved.

\section{Introduction}

In 2008, there were more than 300,000 alcohol-related automobile crashes in the United States (NHTSA, 2009). While drunk-driving crashes have declined substantially over the past three decades, drunk driving is still a serious problem and the leading cause of deaths on highways (Dang, 2008; NHTSA, 2009). Alcohol consumption has been found to explain much of the variation in drunk-driving crashes (Berger and Snortum, 1986; Young and Bielinska-Kwapisz, 2006), but drunk-driving crashes may also be affected by gasoline price changes. Gasoline prices are found to affect automobile crashes negatively in general-higher gasoline prices lead to fewer traffic crashes (e.g., Grabowski and Morrisey, 2004, 2006; Leigh and Geraghty, 2008; Leigh et al., 1991; Wilson et al., 2009). However, to our best knowledge, no studies have investigated gasoline price effects on drunk-driving crashes. This study attempts to fill the gap in the literature by examining the effects of gasoline prices on drunk-driving crashes.

\footnotetext{
* Corresponding author at: Department of Sociology and Social Science Research Center, Mississippi State University, PO Box C, Mississippi State, MS 39762, USA. Tel.: +1 662325 7872; fax: +1 6623257966

E-mail address: gchi@ssrc.msstate.edu (G. Chi).
}

Gasoline price changes may affect drunk-driving crashes in two possible directions-positive and negative. On one hand, higher gasoline prices may lead to fewer drunk-driving crashes. Such a relationship can come about through four possible paths. First, from the economic perspective, higher gasoline prices reduce purchases of alcohol for consumption, which in turn may reduce drunkdriving frequency and crash likelihood. The relationship between economic conditions (e.g., per capita income and employment rate) and drunk-driving crashes is found to be positive (Ruhm, 1996). When gasoline prices increase, discretionary expenditures for alcohol consumption may decrease. Consequently, people may consume less alcohol or drink at bars less often. People may also drink at bars or restaurants closer to their homes in order to reduce gasoline usage. Most empirical evidence suggests that alcohol consumption levels tend to be lower during poor economic conditions (e.g., Nelson, 1997; Ruhm, 1995; Ruhm and Black, 2002; Sloan et al., 1995). Lower alcohol consumption levels, in turn, are linked to fewer drunk-driving crashes (Berger and Snortum, 1986) and fatalities (Benson et al., 1999; Dang, 2008; Wilkinson, 1987; Young and Bielinska-Kwapisz, 2006).

Second, rising gasoline prices could cause some drivers to switch from personal vehicle usage to other transportation modes, such as public transportation, carpooling, biking, or walking (Currie and Phung, 2007, 2008; Haire and Machemehl, 2007). Third, a large 
body of literature suggests that higher gasoline prices reduce gasoline consumption and travel demand (see Goodwin et al., 2004 for a summary of the literature), which in turn reduces people's exposure to all types of crashes, including drunk-driving crashes. Fourth, there is some evidence that surging gasoline prices could cause drivers to drive more cautiously, such as driving more slowly and reducing sudden speeding and braking in order to increase fuel economy (Dahl, 1979; U.S. Congressional Budget Office, 2008). These behaviors then lower drivers' overall crash risk. This causal relationship may also apply to drunk drivers, especially those who are lightly intoxicated.

On the other hand, it is possible that higher gasoline prices will lead to more drunk-driving crashes. Some individual-level studies suggest that individuals consume more alcohol in response to the stress they face during economic hardship. For example, Dee (2001) found elevated rates of binge drinking during periods of high unemployment rates. Others have also found a connection between alcohol consumption and job loss (Catalano et al., 1993; Ettner, 1997) and personal economic strain (Pearlin and Radabaugh, 1976; Peirce et al., 1994). Higher gasoline prices could contribute to the economic stress of individuals, which in turn leads to an increase in alcohol consumption and alcohol-related crashes.

While both hypotheses about the relationship between changing gasoline prices and drunk-driving crashes seem reasonable, they are also contradictory. Our goal in this research is to test the two alternative hypotheses empirically. Specifically, we examine the effects of gasoline prices on drunk-driving crashes in Mississippi by age, gender, and race from 2004 to 2008. Drunk-driving crashes are partitioned into three types: fatal, injury, and property damage only (PDO). We also analyze gasoline price effects on all crashes in the same manner for comparison purposes. Most existing alcohol-related studies examine only fatal drunk-driving crashes (Kenkel, 1993). While fatal drunk-driving crashes evoke a more emotional response, they comprise only a small percentage of drunk-driving crashes. In fact, only $12.6 \%$ of all alcohol-related crashes in 2008 in the U.S. were fatal (NHTSA, 2009). By analyzing fatal, injury, and PDO drunk-driving crashes separately, we are able to gain a more comprehensive understanding of the relationship between gasoline prices and alcohol-related crashes. In the following sections, we first introduce our data and methodology, and then we report our findings on the relationship between gasoline prices and the three types of drunk-driving crashes by age, gender, and race.

\section{Data and methods}

\subsection{Data}

The data used for this study include information on drunkdriving crashes and all crashes (both by fatal, injury, and PDO categories) as well as monthly per-gallon gasoline prices. We also obtained data on the crashes that allowed for analysis of crashes per vehicle miles traveled, crashes per capita, and the age, gender, and race of each driver involved. Drunk-driving crashes could also be affected by several other factors. As such, we included several such variables as controls in our analysis of the relationship between gasoline prices and drunk-driving crashes. These control variables are alcohol consumption, unemployment rate, and seat belt usage. Drunk-driving crashes could also be affected by other variables, including driving behaviors, vehicle characteristics, road conditions, and weather (Fu, 2008). However, our data reflect drunk-driving crashes in Mississippi at the monthly level, and these other factors cannot be easily aggregated to the state level and presumably have much less explanatory effect on traffic safety than at the individual level. Therefore, these factors are not used in this study.

\subsubsection{Drunk-driving crashes}

Researchers examining factors that influence vehicle crashes generally use crash rates generated from data provided by the Fatal Accident Reporting System of the National Highway Traffic Safety Administration (e.g., Grabowski and Morrisey, 2004; Leigh et al., 1991; Wilson et al., 2009). These data enumerate all of the fatal crashes in the U.S. but do not contain information on injury and PDO crashes. As described previously, the majority of drunkdriving crashes are nonfatal, so using data for only fatal crashes cannot provide adequate analysis of the effects of gasoline prices on drunk-driving crashes of all types.

This study uses data enumerating fatal, injury, and PDO drunkdriving crashes to analyze the effects of gasoline prices. The Mississippi Highway Patrol (MHP) provided data on the three types of drunk-driving crashes in Mississippi at the monthly level from April 2004 to December 2008, which was a period of great fluctuation in gasoline prices. However, the data were only available for 57 months; this small number of observations could substantially limit the statistical results. A crash was considered a drunk-driving crash if at least one of the drivers was determined to have a blood alcohol content (BAC) of $0.08 \mathrm{~g} / \mathrm{dl}$ or higher (Robertson et al., 2009). For each drunk-driving crash, the MHP data included the crash type as well as the age, gender, and race of each driver, which allowed us to examine gasoline price effects on drunk-driving crashes by these different crash types and different demographic groups. We also combined crash data with transportation data from the Mississippi Department of Transportation to calculate crashes per vehicle miles traveled (VMT) and with annual population estimations from the U.S. Bureau of the Census to calculate crashes per capita.

In Mississippi, the only crashes that are not mandated to be reported are PDO crashes with property losses less than $\$ 500$. All fatal, injury, and alcohol-related crashes are required to be reported regardless of the property loss involved. However, it is known that police reports of drunk-driving conditions are not always accurate, and minor crashes are often not reported to police (Kim et al., 1995). In addition, about $2 \%$ of law enforcement agencies in Mississippi did not report crashes electronically in the studied period and thus their crashes are not included in the data analysis (personal communication with Captain Randy Ginn, Mississippi Highway Patrol, June 21,2010 ). As we focused on crash counts rather than crash rates in this study, the impacts of under-reporting should not be serious (Kim et al., 1995).

\subsubsection{Gasoline prices}

We obtained monthly per-gallon prices for regular-grade unleaded gasoline from the U.S. Department of Energy's Energy Information Administration (EIA) for the period 2004-2008. Because the EIA does not provide gasoline prices at the state level, we approximated Mississippi prices using average prices from states in the Gulf Coast region. Gasoline prices are adjusted for inflation (in January 2009 dollars) and are used as the primary explanatory variable.

\subsubsection{Alcohol consumption}

Alcohol consumption has direct effects on drunk-driving crashes (Benson et al., 1999; Berger and Snortum, 1986; Dang, 2008; Wilkinson, 1987; Young and Bielinska-Kwapisz, 2006). Because safe-driving capabilities are impaired by alcohol consumption, drunk-driving crashes generally rise with per capita alcohol consumption. Alcohol consumption is often measured using the driver's BAC level in existing drunk-driving studies (Mayhew et al., 2003; Roudsari et al., 2009; Schwilke et al., 2006). Alcohol consumption is also measured using alcohol consumption (in gallons) 
per capita in studies of gasoline prices and traffic safety (Leigh et al., 1991; Noland, 2005). As this study is conducted at the aggregated level, we could not use each individual driver's BAC level. Thus, we used annual alcohol consumption per capita measure provided by the Beer Institute (2009). This measure reflects the amount (in gallons) of alcohol per capita shipped to wholesalers in Mississippi each year. This annual measure does not provide an accurate estimate of alcohol consumption at the monthly level, however, which is a weakness of this study.

\subsubsection{Unemployment rate}

Economic conditions have also been found to affect individuals' consumption of both gasoline and alcohol which, in turn, may affect drunk-driving crashes. To control for the effect of economic conditions on drunk-driving crashes, we included monthly unemployment rates obtained from the U.S. Bureau of Labor Statistics (2009).

\subsubsection{Seat belt usage}

Seat belt usage has been shown to influence traffic crashes. Most studies support the hypothesis that seat belt usage lowers traffic fatality rates, but some research shows that drivers react to wearing a seat belt by increasing risky driving behaviors (Evan and Graham, 1991). In most studies, seat belt usage is usually represented as a simple dummy variable indicating whether or not a seat belt law is in effect in a particular area or time (e.g., Grabowski and Morrisey, 2004). This type of measure may not truly reflect seat belt usage, as compliance with the law may still vary even when a seat belt law is in effect. Therefore, to better measure actual seat belt usage, we use data from an annual roadside survey of Mississippi drivers conducted by the Social Science Research Center of Mississippi State University, who had prepared it for the Mississippi Department of Public Safety. The values in this measure reflect the percentage of drivers who were wearing their seat belts at the time of the survey.

\subsection{Methods}

In this study, we first visualize the relationships between gasoline price changes and total drunk-driving crashes as well as crashes by age (15-23 and 24+ years old), gender (male and female), and race (white and black). ${ }^{1}$ We then investigate gasoline price effects on drunk-driving crashes in regression analyses. We also examine the effects on all crashes for comparison purposes. In total, there are 56 crash measures: 28 for drunk-driving crashes and 28 for all crashes. Each set is composed of all crash types (fatal, injury, PDO, and total) by all demographic groups (young, adult, male, female, white, black, and total). The exhaustive list of crash measures is meant to help provide a comprehensive understanding of gasoline price effects on drunk-driving crashes. Each crash measure is modeled as a function of gasoline prices, alcohol consumption, unemployment rate, and seat belt usage.

Poisson distribution and negative binomial distribution are often used to describe crash counts (Long, 1997). The negative binomial distribution is more appropriate if the data are over-dispersed. Our analysis suggests that 52 of the 56 crash measures exhibit overdispersion. Thus, negative binomial regression models are used for all crash measures, which makes the comparison of model results easier. In addition, populations of young, adult, male, female, white,

\footnotetext{
${ }^{1}$ Crashes of Hispanic drivers are not examined in this study. Hispanics make up a very small proportion of the population in Mississippi-only $2.2 \%$ of the population was of Hispanic origin in 2008 (U.S. Bureau of Census, 2010). This makes the drunkdriving crash counts for Hispanics low (ranging from 2 to 23 per month), which weakens the robustness of the results.
}

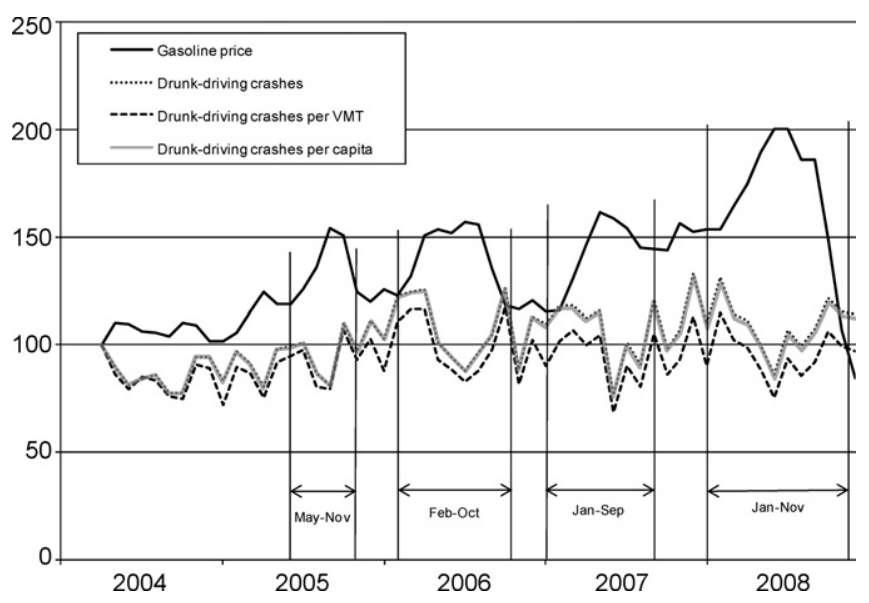

Fig. 1. Gasoline prices and drunk-driving crashes, April 2004-December 2008, Mississippi. Note: Both gasoline prices and drunk-driving crashes are standardized by indices (the first week of April 2004=100) to better visualize the association between their corresponding lines.

black, and total residents are used as exposure variables in corresponding regression models.

\section{Results}

\subsection{Gasoline prices and total drunk-driving crashes}

In Fig. 1, we illustrate the relationship between gasoline prices and total drunk-driving crash counts, total drunk-driving crashes per million VMT, and total drunk-driving crashes per capita. It appears that there is a negative relationship between gasoline prices and total drunk-driving crash counts as well as crashes per VMT and per capita throughout the 57 months of this study. For each spike in gasoline prices, there is a concurrent (or nearly concurrent) dip in drunk-driving crashes. For each dip in gasoline prices, there is a concurrent rise in drunkdriving crashes. This pattern is most pronounced in May-November 2005, February-October 2006, January-September 2007, and January-November 2008. For example, in February-October 2006, the fluctuation in drunk-driving crashes is almost a mirror image of the fluctuation in gasoline prices. Notice that the three measures of crashes follow very similar patterns and that there is a large amount of overlay between them. Note that because the VMT estimates do not include variations by age, gender, and race, we focus on crash counts as dependent variables and population as exposure variables for the rest of the analysis.

After visualizing the relationships between gasoline prices and drunk-driving crashes, we examine the effects of gasoline prices on total drunk-driving crashes at the monthly level using the negative binomial regression model (see Appendix A for the results of the analysis). Table 1 presents the elasticities of crashes per capita with respect to gasoline prices and alcohol consumption. The elasticities are calculated using the studied period's averages of $\$ 2.60$ for gasoline prices and 27.18 gal for alcohol consumption. In total, we find that gasoline prices have negative effects on drunkdriving crashes-higher gasoline prices lead to fewer drunk-driving crashes. In contrast, alcohol consumption has positive effects on drunk-driving crashes-higher alcohol consumption leads to more drunk-driving crashes. The total drunk-driving crashes are then partitioned into fatal, injury, and PDO crashes. The results show that gasoline prices have effects on reducing only PDO drunk-driving crashes. Alcohol consumption has effects on increasing only fatal and injury drunk-driving crashes; the effects are stronger on fatal crashes than on injury crashes. 
Table 1

Elasticities of crashes per capita with respect to gasoline prices and alcohol consumption, April 2004-December 2008, Mississippi.

\begin{tabular}{|c|c|c|c|c|c|c|c|c|}
\hline & \multicolumn{4}{|c|}{ Drunk-driving crashes } & \multicolumn{4}{|c|}{ All crashes } \\
\hline & Fatal & Injury & PDO & Total & Fatal & Injury & PDO & Total \\
\hline \multicolumn{9}{|l|}{ Total } \\
\hline Gasoline prices & & & -0.309 & -0.205 & & & -0.211 & \\
\hline Alcohol consumption & 24.112 & 12.637 & & 7.545 & 13.204 & 9.282 & 2.015 & 13.205 \\
\hline \multicolumn{9}{|l|}{ Young (ages 15-23) } \\
\hline Gasoline prices & & & & -0.325 & & & -0.190 & -0.148 \\
\hline Alcohol consumption & & & & 6.732 & 9.115 & 7.896 & 1.396 & 3.173 \\
\hline \multicolumn{9}{|l|}{ Adult (age 24+) } \\
\hline Gasoline prices & & & -0.291 & -0.182 & & & -0.216 & -0.156 \\
\hline Alcohol consumption & 28.416 & 13.495 & & 7.117 & 14.553 & 9.805 & 2.198 & 4.241 \\
\hline \multicolumn{9}{|l|}{ Male } \\
\hline Gasoline prices & & & -0.270 & & & & -0.187 & -0.120 \\
\hline Alcohol consumption & 21.364 & 10.228 & & 5.920 & 14.207 & 9.296 & 2.005 & 3.989 \\
\hline \multicolumn{9}{|l|}{ Female } \\
\hline Gasoline prices & & & & -0.393 & & & -0.234 & -0.192 \\
\hline Alcohol consumption & 50.684 & 24.068 & & 11.957 & 10.272 & 9.258 & 1.988 & 3.925 \\
\hline \multicolumn{9}{|l|}{ White } \\
\hline Gasoline prices & & & -0.348 & -0.231 & & & -0.226 & -0.164 \\
\hline Alcohol consumption & 27.074 & 16.580 & & 9.128 & 13.499 & 10.169 & 2.799 & 4.724 \\
\hline \multicolumn{9}{|l|}{ Black } \\
\hline Gasoline prices & & -0.569 & -0.463 & -0.476 & & & -0.224 & -0.169 \\
\hline Alcohol consumption & 29.650 & 13.252 & & 8.725 & 14.114 & 8.158 & & 1.898 \\
\hline
\end{tabular}

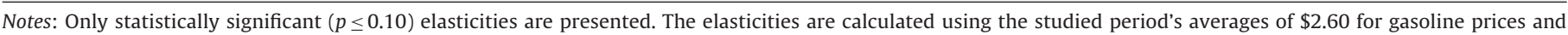
27.18 gal for alcohol consumption.

We also examine the effects of gasoline prices on all crashes using the same three crash types for comparison purposes. Gasoline prices have no effects on reducing total crashes but negative effects on PDO crashes. In contrast, alcohol consumption has effects on all crash types: fatal crashes, injury crashes, PDO crashes, and total crashes. The effects decrease as the crash severity decreases: the effects are stronger on fatal crashes than on injury crashes and stronger on injury crashes than on PDO crashes.

Comparison of the corresponding elasticities between drunkdriving crashes and all crashes indicates that the effects of gasoline prices and alcohol consumption on the former are generally stronger than on the latter. Gasoline prices have stronger effects on drunk-driving PDO crashes than on all PDO crashes. Alcohol consumption has stronger effects on fatal drunk-driving crashes than on all fatal crashes and stronger effects on injury drunkdriving crashes than on all injury crashes. The only exception is alcohol consumption's effects on total drunk-driving crashes and all crashes, in which the former is less; this is possibly due to the fact that alcohol consumption has no significant effects on drunk-driving PDO crashes but does for all PDO crashes. These results are based on totals for drunk-driving crashes and all crashes. There may exist variations by age, gender, and race. Therefore, in the following subsections we further examine the effects of gasoline prices and alcohol consumption on drunk-driving crashes and all crashes by these demographic groups.

\subsection{Variations by age}

The relationship between gasoline prices and drunk-driving crashes by age is illustrated in Fig. 2. Drunk-driving crashes are separated into two groups: crashes involving young drivers (ages 15-23) and crashes involving adult drivers (age 24 and over). For each spike in gasoline prices, there is generally a concurrent (or nearly concurrent) dip in drunk-driving crashes of young and adult drivers. For each dip in gasoline prices, there is generally a concurrent rise in drunk-driving crashes of young and adult drivers. This pattern is more apparent in July-December 2005, March-November 2006, March-October 2007, and February-November 2008.
Next we examine the effects of gasoline prices on drunk-driving crashes and all crashes of young and adult drivers separately (see Appendix B). For young drivers, higher gasoline prices lead to fewer total drunk-driving crashes, and higher alcohol consumption leads to higher total drunk-driving crashes. However, neither gasoline prices nor alcohol consumption have significant effects by crash type: fatal, injury, and PDO drunk-driving crashes. Gasoline prices have effects on reducing all crashes for young drivers and alcohol consumption has effects on increasing all crashes for young drivers. Although the pattern is similar to that of the effects on total drunkdriving crashes, the effects on all crashes are weaker than those on drunk-driving crashes. In addition, gasoline prices have effects on reducing all PDO crashes. Alcohol consumption has effects on increasing fatal crashes, injury crashes, and PDO crashes, and the effects decrease as the crash severity decreases.

For adult drivers, the findings are similar to those for total drivers. First, gasoline prices have negative effects on drunk-driving crashes and all crashes; alcohol consumption has positive effects on

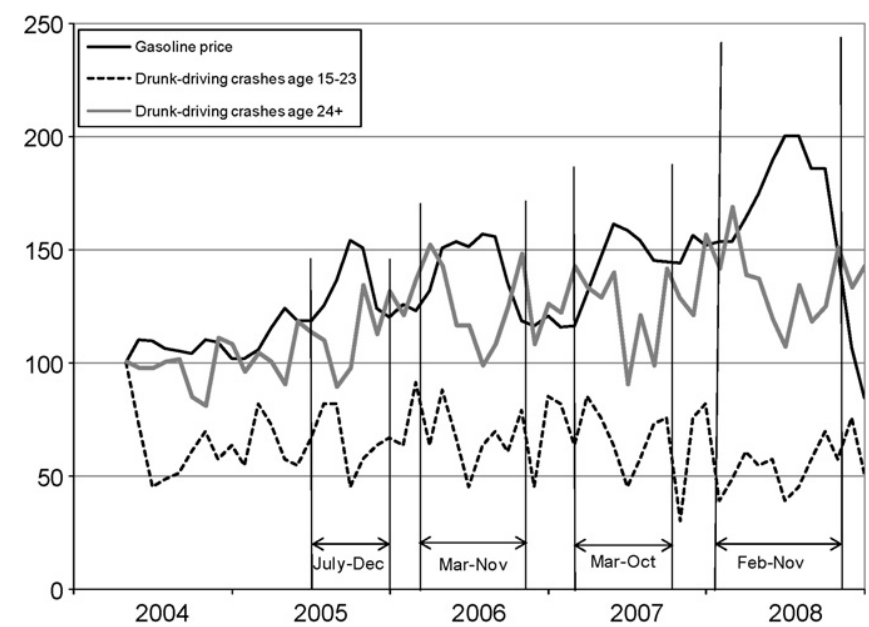

Fig. 2. Gasoline prices and drunk-driving crashes by age, April 2004-December 2008, Mississippi. Note: Both gasoline prices and drunk-driving crash counts are standardized by indices (the first week of April 2004=100) to better visualize the association between their corresponding lines. 


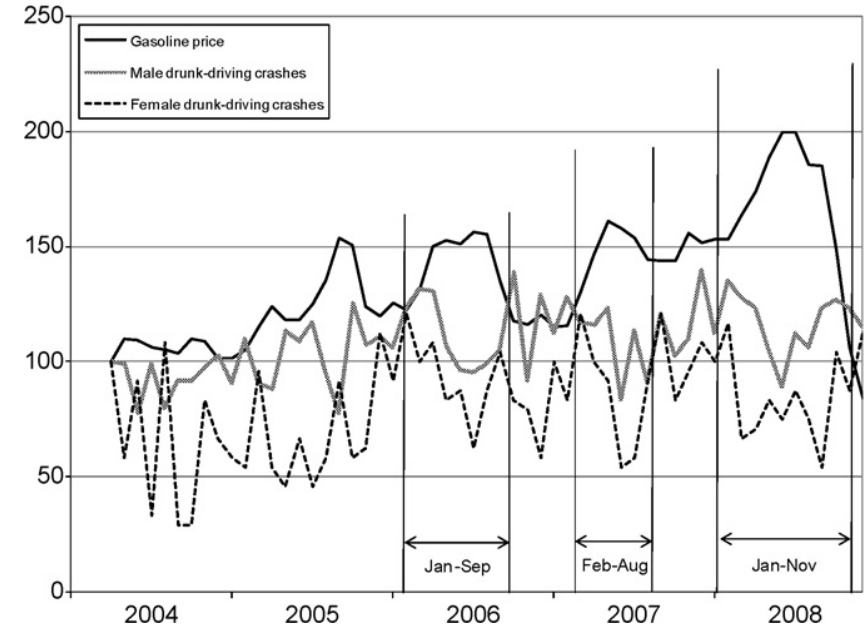

Fig. 3. Gasoline prices and drunk-driving crashes by gender, April 2004-December 2008, Mississippi. Note: Both gasoline prices and drunk-driving crash counts are standardized by indices (the first week of April $2004=100$ ) to better visualize the association between their corresponding lines.

both. The effects on drunk-driving crashes are stronger than on all crashes. Second, within each crash type, gasoline prices have effects only on PDO crashes and the effects are stronger on drunk-driving PDO crashes than on all PDO crashes. Alcohol consumption has effects on both fatal and injury crashes, and the effects are stronger on fatal and injury drunk-driving crashes than on all fatal and injury crashes. The effects decrease as the crash severity decreases.

\subsection{Variations by gender}

The relationships between gasoline prices and both male and female drunk-driving crashes are depicted in Fig. 3. An inverse relationship between gas prices and drunk-driving crashes can be observed for both males and females, especially during the periods in which gas prices rose and fell the most. This pattern is especially strong in the periods of February-September 2006, February-September 2007, and January-November 2008. In addition, the inverse relationship seems to be more pronounced for females. For example, from February-September in 2007 when gasoline prices spiked, there were greater dips for female drunkdriving crashes than for male crashes.

We then examine the effects of gasoline prices on drunk-driving crashes and all crashes by males and females (see Appendix C). For male drivers, gasoline prices do not have effects on reducing total drunk-driving crashes but do have effects on all crashes. Gasoline prices also have effects on PDO drunk-driving crashes and all PDO crashes, and the effects on the former are stronger than on the latter. The effects of alcohol consumption on male drivers are similar to those on adult drivers. Alcohol consumption has positive effects on total drunk-driving crashes and all crashes, with the former effects being stronger. Alcohol consumption has effects on fatal and injury drunk-driving crashes, with the former effects being stronger. Alcohol consumption also has effects on all fatal, injury, and PDO crashes, with decreasing effects as the crash severity decreases.

For females, gasoline price effects are similar to those found for young drivers. Gasoline prices have negative effects on total drunk-driving crashes but not on any specific drunk-driving crash types. Gasoline prices also have negative but weaker effects on all crashes. In addition, gasoline prices have negative effects on all PDO crashes. The effects of alcohol consumption on female drivers are similar to those on male drivers and adult drivers. Alcohol consumption has positive effects on total drunk-driving crashes and

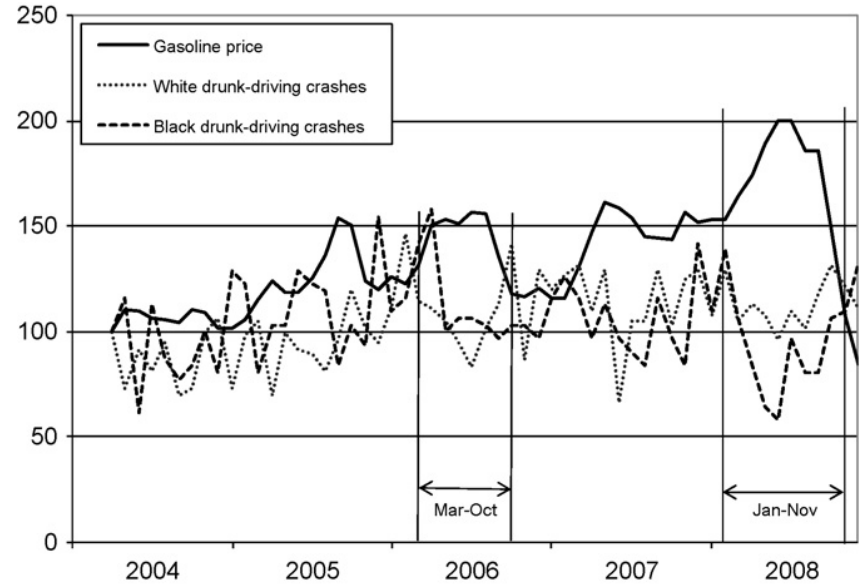

Fig. 4. Gasoline prices and drunk-driving crashes by race, April 2004-December 2008, Mississippi. Note: Both gasoline prices and drunk-driving crash counts are standardized by indices (the first week of April $2004=100$ ) to better visualize the association between their corresponding lines.

all crashes, with stronger effects on the former. Alcohol consumption has effects on fatal and injury drunk-driving crashes, with the former effects being stronger. Alcohol consumption also has effects on all fatal, injury, and PDO crashes, with decreasing effects as the crash severity decreases.

\subsection{Variations by race}

Fig. 4 displays the relationship between gasoline prices and drunk-driving crashes for white and black drivers. In general, gasoline prices have negative associations with drunk-driving crashes for both racial groups. This pattern is most obvious from March to October 2006 and from January to November 2008. However, the associations are relatively weak compared to those among age and gender groups.

We next examine the effects of gasoline prices on drunk-driving crashes and all crashes by race (see Appendix D). For white drivers, gasoline prices have similar effects as for adult drivers. Gasoline prices have negative effects on total drunk-driving crashes and all crashes, with stronger effects on the former. Gasoline prices also have effects on drunk-driving PDO crashes and all PDO crashes, again, with the former effects stronger. Gasoline prices do not have effects on fatal and injury crash types. Alcohol consumption's effects on white drivers are similar to those on adult drivers and male drivers. Alcohol consumption has positive effects on total drunk-driving crashes and all crashes, with the former effects being stronger. Alcohol consumption has effects on fatal and injury drunk-driving crashes, with stronger effects on the former. Alcohol consumption also has effects on all fatal, injury, and PDO crashes, with decreasing effects as the crash severity decreases.

For black drivers, the findings are slightly different from the others. Gasoline prices have negative effects on total drunk-driving crashes and all crashes, with the former effects being stronger. Gasoline prices also have negative effects on drunk-driving PDO crashes and all PDO crashes, with the former effects being stronger. However, gasoline prices have effects on drunk-driving injury crashes of black drivers-the only significant effects of gasoline prices on drunk-driving injury crashes. Alcohol consumption effects are stronger on total drunk-driving crashes than on all crashes, stronger on fatal drunk-driving crashes than on all fatal crashes, stronger on drunk-driving injury crashes than on all injury crashes, stronger on fatal types than on injury types, and nonexistent on PDO types. 


\section{Conclusions and discussion}

\subsection{Conclusions}

A small body of literature suggests that gasoline price changes affect traffic crashes. However, the effects of gasoline price changes on drunk-driving crashes specifically have not been studied. This study attempts to fill this gap in the literature by examining gasoline price effects on drunk-driving crashes by several crash types (fatal, injury, and PDO) and demographic groups (age, gender, and race) at the monthly level from April 2004 to December 2008 in Mississippi. For comparison purposes, we also analyze the effects of gasoline prices and alcohol consumption on all crashes. Our analysis shows that when gasoline prices are higher, there are fewer drunk-driving crashes, particularly among PDO crashes. When alcohol consumption levels are higher, there are more drunkdriving crashes, particularly among fatal and injury crashes. The effects of gasoline prices and alcohol consumption are stronger on drunk-driving crashes than on all crashes. The findings do not vary much across different demographic groups. Overall, gasoline prices have greater effects on less severe drunk-driving crashes and alcohol consumption has greater effects on more severe drunk-driving crashes.

\subsection{Discussion}

The main findings are discussed in this subsection. For drunkdriving crashes, gasoline prices have effects on PDO crashes but not on fatal and injury crashes. The fact that gasoline prices have greater effects on less severe crashes may be because higher gasoline prices are more likely to deter lighter drinkers from drunk driving. Lighter drinkers are more likely to be involved in less severe crashes but less likely to be involved in fatal and injury crashes. In contrast, higher gasoline prices are less likely to deter heavier drinkers from drunk driving, as heavier drinkers are less likely to change driving behaviors due to gasoline price changes and may even drink more in response to economic stress. Therefore, gasoline prices have greater effects on PDO crashes but little effects on fatal and injury crashes.

Alcohol consumption has greater effects on fatal and injury crashes than on PDO crashes, and the effects decrease as the crash severity decreases. This may be due to the fact that the change in alcohol consumption is mainly caused by changes in alcohol consumption among existing drinkers rather than among individuals moving into drinking behaviors (Ruhm and Black, 2002). Higher alcohol consumption levels increase the likelihood of drivers being involved in more severe crashes. In addition, unemployment rates generally have moderately positive effects on drunk-driving crashes. Higher unemployment rates, which often occur in economic downturn, are associated with increases in alcohol consumption, especially in the form of binge drinking (Dee, 2001).

The effects of gasoline prices and alcohol consumption are stronger on drunk-driving crashes than on all crashes. The increase in gasoline prices likely reduces expenditures for alcohol consumption (Meyer, 2004), which in turn reduces drunk-driving crashes. However, essential travel like driving to work is less likely to be affected by gasoline price changes. Thus, gasoline price effects on drunk-driving crashes (typically not made on work commutes) are stronger than on all crashes. Alcohol consumption has greater effects on drunk-driving crashes than on all crashes because it is generally a direct causal factor in drunk-driving crashes.

\subsection{Limitations and future research}

The results of this study are limited by the small number of observations (only 57 months in one state). Future research could use a longer time period covering both economic growth and recession. Also, this study is focused on only the state of Mississippi, a rural southern state in the U.S. Future research could examine other geographic areas, such as northern or western states or metropolitan areas. Doing so would provide a more comprehensive understanding of gasoline price effects on drunk-driving crashes.

\section{Acknowledgements}

The authors would like to thank Neal Feierabend and Lee Weiskopf of the Social Science Research Center at Mississippi State University for assistance in deriving traffic crash data, and Michael Iacono of the Department of Civil Engineering at the University of Minnesota for reviewing earlier drafts of this manuscript. Appreciation is extended to Bill Ponicki of the Preventive Research Center of the Pacific Institute for Research and Evaluation for providing the alcohol consumption data, and to Trung Trinh of the Mississippi Department of Transportation Planning Division for providing the monthly vehicle miles traveled data. This research was supported by a grant from Mississippi Office of Highway Safety entitled "Public Safety Data Laboratory” (award number 09 K9 401-1). Director Kim Proctor and researcher Ron Sennett of the Office of Highway Safety and Captain Randy Ginn of the Mississippi Highway Safety Patrol have been very helpful in facilitating this research. 
Appendix A. Results of negative binomial regression models for crashes, April 2004-December 2008, Mississippi

\begin{tabular}{|c|c|c|c|c|c|c|c|c|}
\hline & \multicolumn{4}{|l|}{ Drunk-driving crashes } & \multicolumn{4}{|l|}{ All crashes } \\
\hline & Fatal & Injury & PDO & Total & Fatal & Injury & PDO & Total \\
\hline Gasoline prices & $0.00047(0.00159)$ & $-0.00029(0.00060)$ & $-0.00119^{* *}(0.00046)$ & $-0.00079^{*}(0.00038)$ & $0.00032(0.00048)$ & $-0.00003(0.00027)$ & $-0.00081^{* * *}(0.00023)$ & $0.00032(0.00048)$ \\
\hline Alcohol consumption & $0.88714^{* * *}(0.27037)$ & $0.46493^{* * *}(0.09796)$ & $0.07575(0.07800)$ & $0.27760^{* * * *}(0.06208)$ & $0.48578^{* * * *}(0.07820)$ & $0.34149^{* * * *}(0.04279)$ & $0.07412^{*}(0.03592)$ & $0.48582^{* * * *}(0.07823)$ \\
\hline State unemployment & $-0.06395(0.08725)$ & $-0.03967(0.03133)$ & $0.04015^{\dagger}(0.02385)$ & $0.00782(0.01934)$ & $0.03838(0.02344)$ & $0.01822(0.01312)$ & $0.03829^{* * * *}(0.01109)$ & $0.03879^{\dagger}(0.02344)$ \\
\hline Seat belt usage & $-0.05334^{*}(0.02493)$ & $-0.02669^{* *}(0.00947)$ & $0.01998^{* *}(0.00761)$ & $-0.00005(0.00604)$ & $-0.03513^{* * *}(0.00752)$ & $-0.02004^{* * *}(0.00426)$ & $-0.00466(0.00360)$ & $-0.03515^{* * *}(0.00753)$ \\
\hline $\begin{array}{l}\text { Constant } \\
\text { Statistics }\end{array}$ & $-26.73547^{* * *}(6.52464)$ & $-14.84743^{* * *}(2.32192)$ & $-7.17326^{* * *}(1.82591)$ & $-15.71386^{* * *}(1.46152)$ & $-14.89322^{* * *}(1.85408)$ & $-8.19466^{* * *}(1.00226)$ & $-0.84357(0.84306)$ & $-14.89489^{* * *}(1.85470)$ \\
\hline Log likelihood & -125.405 & -191.212 & -205.622 & -223.046 & -216.374 & -385.137 & -432.951 & -216.407 \\
\hline AIC & 262.811 & 394.423 & 423.244 & 458.093 & 444.747 & 782.274 & 877.901 & 444.814 \\
\hline & 275.069 & 406.682 & 435.502 & 470.351 & 457.006 & 794.532 & 890.160 & 457.072 \\
\hline Observations & 57 & 57 & 57 & 57 & 57 & 57 & 57 & 57 \\
\hline
\end{tabular}

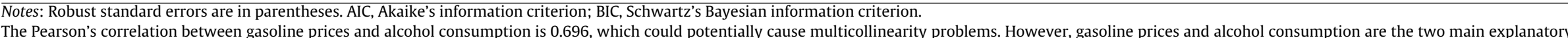
The Pearson's correlation between gasoline prices and alcohol consumption is 0.696 , which could potentially cause multicollinearity problems. However, gasoline prices and alco
variables in this study. We want to investigate and compare their individual effects on crashes in each model. As such, we use the two individual variables together in the models.

${ }_{* *}^{*} p \leq 0.05$.

$p \leq 0.01$.

$p \leq 0.001$

${ }^{\dagger} p \leq 0.10$.

Appendix B. Results of negative binomial regression models for crashes by age, April 2004-December 2008, Mississippi

\begin{tabular}{|c|c|c|c|c|c|c|c|c|}
\hline & \multicolumn{4}{|l|}{ Drunk-driving crashes } & \multicolumn{4}{|l|}{ All crashes } \\
\hline & Fatal & Injury & PDO & Total & Fatal & Injury & PDO & Total \\
\hline \multicolumn{9}{|l|}{ Young } \\
\hline Gasoline prices & $-0.00071(0.00437)$ & $-0.00094(0.00131)$ & $-0.00150(0.00095)$ & $-0.00125^{\dagger}(0.00076)$ & $0.00159(0.00122)$ & $-0.00019(0.00032)$ & $-0.00073^{* \prime \prime}(0.00025)$ & $-0.00057^{\circ}(0.00024)$ \\
\hline Alcohol consumption & $0.68771(0.54516)$ & $0.32365(0.20110)$ & $0.17566(0.15048)$ & $0.24770^{*}(0.11738)$ & $0.33534^{\dagger}(0.17190)$ & $0.29050^{*+1}(0.05001)$ & $0.05136(0.03904)$ & $0.11674^{* \prime \prime}(0.03848)$ \\
\hline State unemployment & $-0.12129(0.17931)$ & $-0.17970^{*}(0.07306)$ & $0.01319(0.04672)$ & $-0.05063(0.03841)$ & $-0.01308(0.05160)$ & $-0.02174(0.01542)$ & $0.00838(0.01207)$ & $0.00009(0.01188)$ \\
\hline Seat belt usage & $-0.17785^{\prime \prime \prime}(0.06166)$ & $-0.02270(0.02012)$ & $-0.01623(0.01507)$ & $-0.02474^{*}(0.01179)$ & $-0.10125^{\prime \prime \prime \prime}(0.01762)$ & $-0.03762^{*+1}(0.00496)$ & $-0.02615^{\prime \prime \prime+}(0.00390)$ & $-0.02973^{\cdots+*}(0.00383)$ \\
\hline $\begin{array}{l}\text { Constant } \\
\text { Statistics }\end{array}$ & $-19.17709(12.86130)$ & $-16.87069+\cdots$ & $-13.85997^{* * *}(3.50853)$ & $-14.39533^{* \prime \prime \prime}(2.74692)$ & $-13.07435^{* * *}(4.07210)$ & $-11.75003^{* *+*}(1.17162)$ & $-5.06686^{* * * *}(0.91538)$ & $-6.272688^{* \cdots \prime}(0.90197)$ \\
\hline $\begin{array}{l}\text { Statistics } \\
\text { Log likelihood }\end{array}$ & -67.658 & -133.220 & -144.632 & -164.616 & & & & \\
\hline AIC & 145.316 & 278.440 & 299.265 & 341.232 & $\begin{array}{r}-1 / 0.395 \\
352.790\end{array}$ & $\begin{array}{r}-314.294 \\
640.589\end{array}$ & $\begin{array}{l}-357.100 \\
776200\end{array}$ & -374.493 \\
\hline $\begin{array}{l}\text { AIC } \\
\text { BIC }\end{array}$ & 155.531 & 290.698 & 309.480 & 353.491 & 365.048 & $\begin{array}{l}640.589 \\
652.847\end{array}$ & $\begin{array}{l}726.200 \\
738.458\end{array}$ & $\begin{array}{l}760.985 \\
773.243\end{array}$ \\
\hline Observations & 57 & 57 & 57 & 57 & 57 & 57 & 57 & 57 \\
\hline \multicolumn{9}{|l|}{ Adult } \\
\hline Gasoline prices & $0.00061(0.00164)$ & $-0.00016(0.00063)$ & $-0.00112^{*}(0.00053)$ & $-0.00070^{\dagger}(0.00041)$ & $0.00007(0.00044)$ & $0.00002(0.00028)$ & $-0.00083^{* \cdots *}(0.00024)$ & $-0.00060 "(0.00023)$ \\
\hline Alcohol consumption & $1.04549^{\prime \prime \prime \prime}(0.30853)$ & $0.49650^{*+1 *}(0.10456)$ & $0.04935(0.08976)$ & $0.26183^{*+*}(0.06915)$ & $0.53544=(0.07667)$ & $0.36074^{*+1+1}(0.04377)$ & $0.08088^{*}(0.03810)$ & $0.15605^{\cdots+\prime}(0.03630)$ \\
\hline State unemployment & $-0.05083(0.09818)$ & $-0.01185(0.03282)$ & $0.04660^{\dagger}(0.02732)$ & $0.02041(0.02135)$ & $0.04802^{\circ}(0.02286)$ & $0.03188^{*}(0.01341)$ & $0.04834^{*+1}(0.01176)$ & $0.04367^{* * * *}(0.01119)$ \\
\hline Seat belt usage & $-0.03429(0.02672)$ & $-0.02791^{1+i}(0.01000)$ & $0.02864^{+* 1 *}(0.00870)$ & $0.00448(0.00667)$ & $-0.02155^{* * 1}(0.00717)$ & $-0.01467^{* * 1+}(0.00436)$ & $0.00190(0.00383)$ & $-0.00267(0.00364)$ \\
\hline $\begin{array}{l}\text { Constant } \\
\text { Statistics }\end{array}$ & $-39.11937^{* * *}(7.52910)$ & $-22.49977^{*+*}(2.48644)$ & $-13.76268^{*+* *}(2.10304)$ & $-17.34147^{*+1}(1.63082)$ & $-23.81831^{* * *+}(1.82865)$ & $-15.91087^{* * *}(1.02587)$ & $-8.24662^{*+* *}(0.89459)$ & $-9.70612^{*+1 *}(0.85164)$ \\
\hline Log likelihood & -116.584 & -183.465 & -200.163 & -216.244 & -201.440 & -370.080 & -420.377 & -435.672 \\
\hline AIC & 245.168 & 378.930 & 412.327 & 444.488 & 414.881 & 752.159 & 852.753 & 883.345 \\
\hline BIC & 257.426 & 391.188 & 424.585 & 456.746 & 427.139 & 764.418 & 865.011 & 895.603 \\
\hline Observations & 57 & 57 & 57 & 57 & 57 & 57 & 57 & 57 \\
\hline
\end{tabular}

$p \leq 0.05$.

$p \leq 0.01$

$p \leq 0.001$
$p \leq 0.10$. 
Appendix C. Results of negative binomial regression models for crashes by gender, April 2004-December 2008, Mississippi

\begin{tabular}{|c|c|c|c|c|c|c|c|c|}
\hline & \multicolumn{4}{|l|}{ Drunk-driving crashes } & \multicolumn{4}{|l|}{ All crashes } \\
\hline & Fatal & Injury & PDO & Total & Fatal & Injury & PDO & Total \\
\hline \multicolumn{9}{|l|}{ Male } \\
\hline Gasoline prices & $0.00044(0.00171)$ & $-0.00005(0.00067)$ & $-0.00104^{*}(0.00047)$ & $-0.00063(0.00041)$ & $0.00043(0.00050)$ & $0.00022(0.00026)$ & $-0.00072^{* * *}(0.00022)$ & $-0.00046^{*}(0.00021)$ \\
\hline Alcohol consumption & $0.78603^{* * *}(0.27701)$ & $0.37629^{* * * *}(0.10870)$ & $0.06437(0.07995)$ & $0.21781^{* * *}(0.06821)$ & $0.52269^{* * * * *}(0.08152)$ & $0.34200^{* * * * *}(0.04182)$ & $0.07377^{*}(0.03517)$ & $0.14678^{* * * *}(0.03342)$ \\
\hline State unemployment & $-0.08701(0.09181)$ & $-0.04468(0.03493)$ & $0.04303^{\dagger}(0.02428)$ & $0.00596(0.02128)$ & $0.01786(0.02480)$ & $0.02060(0.01283)$ & $0.03893^{* * * *}(0.01089)$ & $0.03357^{* * *}(0.01032)$ \\
\hline Seat belt usage & $-0.06225^{*}(0.02614)$ & $-0.02145^{*}(0.01057)$ & $0.01792^{*}(0.00778)$ & $-0.00059(0.00665)$ & $-0.03795^{* * *}(0.00780)$ & $-0.02272^{* * *}(0.00416)$ & $-0.00624^{\dagger}(0.00352)$ & $-0.01091^{* * *}(0.00334)$ \\
\hline Constant & $-29.57591^{* * *}(6.66960)$ & $-19.18119^{* * * *}(2.57499)$ & $-13.16911^{* * *}(1.87020)$ & $-15.44110^{* * * *}(1.60591)$ & $-22.10919^{* * *}(1.94222)$ & $-14.88759^{* * * *}(0.98030)$ & $-7.52717^{* * * *}(0.82568)$ & $-8.92079^{* * * *}(0.78405)$ \\
\hline \multicolumn{9}{|c|}{ (0.50000 } \\
\hline Log likelihood & -118.486 & -186.640 & -195.490 & -217.405 & -199.170 & -350.022 & -398.294 & -413.557 \\
\hline AIC & 248.972 & 385.279 & 402.981 & 446.811 & 410.340 & 712.045 & 808.589 & 839.114 \\
\hline BIC & 261.230 & 397.538 & 415.239 & 459.069 & 422.598 & 724.303 & 820.847 & 851.372 \\
\hline Observations & 57 & 57 & 57 & 57 & 57 & 57 & 57 & 57 \\
\hline \multicolumn{9}{|l|}{ Female } \\
\hline Gasoline prices & $0.00076(0.00340)$ & $-0.00136(0.00126)$ & $-0.00177(0.00111)$ & $-0.00151^{\dagger}(0.00085)$ & $0.00008(0.00080)$ & $-0.00032(0.00029)$ & $-0.00090^{* * *}(0.00025)$ & $-0.00074^{* *}(0.00024)$ \\
\hline Alcohol consumption & $1.86477^{*}(0.86303)$ & $0.88552^{* * * *}(0.21399)$ & $0.11860(0.18818)$ & $0.43992^{* * *}(0.14397)$ & $0.37791^{* *}(0.13338)$ & $0.34062^{2 * * * *}(0.04614)$ & $0.07316^{\dagger}(0.03891)$ & $0.14441^{* * * *}(0.03753)$ \\
\hline State unemployment & $0.09811(0.22996)$ & $-0.01504(0.06770)$ & $0.02484(0.05794)$ & $0.00914(0.04457)$ & $0.08627^{*}(0.03856)$ & $0.01533(0.01415)$ & $0.03768^{* *}(0.01197)$ & $0.03173^{* *}(0.01153)$ \\
\hline Seat belt usage & $-0.02456(0.06170)$ & $-0.05248^{* * *}(0.01986)$ & $0.02819(0.01827)$ & $-0.00251(0.01378)$ & $-0.02783^{*}(0.01281)$ & $-0.01700^{* * * *}(0.00458)$ & $-0.00289(0.00390)$ & $-0.00682^{\dagger}(0.00375)$ \\
\hline $\begin{array}{l}\text { Constant } \\
\text { Statistics }\end{array}$ & $-64.70016^{* *}(21.64598)$ & $-32.48506^{* * *}(5.11585)$ & $-16.57270^{* * *}(4.40046)$ & $-22.74463^{* * *}(3.39199)$ & $-20.22694^{* * * *}(3.15739)$ & $-15.32323^{* * *}(1.08177)$ & $-7.96038^{* * *}(0.91301)$ & $-9.32737^{* * * *}(0.88031)$ \\
\hline Log likelihood & -58.261 & -132.787 & -158.682 & -173.929 & -173.881 & -343.564 & -391.247 & -407.256 \\
\hline AIC & 126.522 & 277.574 & 329.364 & 359.859 & 359.762 & 699.127 & 794.495 & 826.513 \\
\hline BIC & 136.737 & 289.832 & 341.622 & 372.117 & 372.021 & 711.386 & 806.753 & 838.771 \\
\hline Observations & 57 & 57 & 57 & 57 & 57 & 57 & 57 & 57 \\
\hline
\end{tabular}

$p \leq 0.05$

*** $p \leq 0.01$.

$p \leq 0.001$

${ }^{\dagger} p \leq 0.10$. 
Appendix D. Results of negative binomial regression models for crashes by race, April 2004-December 2008, Mississippi

\begin{tabular}{|c|c|c|c|c|c|c|c|c|}
\hline & \multicolumn{4}{|l|}{ Drunk-driving crashes } & \multicolumn{4}{|l|}{ All crashes } \\
\hline & Fatal & Injury & PDO & Total & Fatal & Injury & PDO & Total \\
\hline \multicolumn{9}{|l|}{ White } \\
\hline Gasoline prices & $0.00092(0.00214)$ & $-0.00030(0.00075)$ & $-0.00134^{*}(0.00055)$ & $-0.00089^{\dagger}(0.00046)$ & $0.00026(0.00060)$ & $-0.00001(0.00028)$ & $-0.00087^{* * *}(0.00023)$ & $-0.00063^{* *}(0.00022)$ \\
\hline Alcohol consumption & $0.99611^{* *}(0.34714)$ & $0.61001^{* * *}(0.12574)$ & $0.11352(0.09581)$ & $0.33584^{* * *}(0.07745)$ & $0.49665^{* * *}(0.09852)$ & $0.37414^{*+4}(0.04451)$ & $0.10298^{* *}(0.03587)$ & $0.17380^{* * * *}(0.03512)$ \\
\hline State unemployment & $-0.13875(0.11910)$ & $-0.02594(0.03984)$ & $0.07764^{* *}(0.02849)$ & $0.03279(0.02375)$ & $0.03987(0.02939)$ & $0.02286^{\dagger}(0.01363)$ & $0.04172^{* * *}(0.01106)$ & $0.03648^{* * *}(0.01081)$ \\
\hline Seat belt usage & $-0.07735^{*}(0.03217)$ & $-0.02764^{*}(0.01193)$ & $0.02390^{* *}(0.00925)$ & $0.00061(0.00746)$ & $-0.03382^{* * *}(0.00947)$ & )$-0.02504^{* * *}(0.00442)$ & $-0.00853^{*}(0.00360)$ & $-0.01299^{* * *}(0.00351)$ \\
\hline Constant & $-34.71466^{* * *}(8.42733)$ & $-25.78282^{* * *}(2.99572)$ & $-15.60228^{* * *}(2.24190)$ & $-19.40698^{* 2 *}(1.82685)$ & ) $-22.21399^{* * * *}(2.33764)$ & $-15.73046^{* * *}(1.04284)$ & $-8.28617^{* * *}(0.84175)$ & $-9.63775^{* * *}(0.82374)$ \\
\hline \multicolumn{9}{|c|}{ 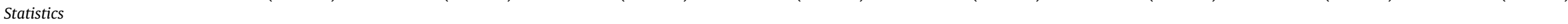 } \\
\hline Log likelihood & -104.936 & -173.183 & -187.376 & -204.936 & -198.135 & -356.436 & -404.049 & -420.405 \\
\hline AIC & 221.872 & 358.367 & 386.751 & 421.873 & 408.270 & 724.872 & 820.099 & 852.810 \\
\hline BIC & 234.130 & 370.625 & 399.009 & 434.131 & 420.529 & 737.131 & 832.357 & 865.069 \\
\hline Observations & 57 & 57 & 57 & 57 & 57 & 57 & 57 & 57 \\
\hline \multicolumn{9}{|l|}{ Black } \\
\hline Gasoline prices & $-0.00013(0.00287)$ & $-0.00219^{*}(0.00108)$ & $-0.00178^{*}(0.00081)$ & $-0.00183^{* *}(0.00060)$ & $0.00029(0.00070)$ & $-0.00017(0.00027)$ & $-0.00086^{* * * *}(0.00026)$ & $-0.00065^{* *}(0.00023)$ \\
\hline Alcohol consumption & $1.09089^{*}(0.54586)$ & $0.48757^{* *}(0.16957)$ & $0.16699(0.13184)$ & $0.32100^{* * *}(0.09626)$ & $0.51929^{* * * *}(0.11368)$ & $0.30013^{*+2}(0.04274)$ & $-0.02159(0.04026)$ & $0.06984^{\dagger}(0.03594)$ \\
\hline State unemployment & $0.13148(0.15314)$ & $-0.01922(0.05373)$ & $-0.01119(0.04173)$ & $-0.00878(0.03050)$ & $0.04566(0.03378)$ & $0.01202(0.01311)$ & $0.03489^{* *}(0.01240)$ & $0.02823^{*}(0.01106)$ \\
\hline Seat belt usage & $-0.04247(0.04836)$ & $-0.04767^{* *}(0.01670)$ & $-0.00522(0.01301)$ & $-0.02264^{*}(0.00947)$ & $-0.04992^{* * *}(0.01093)$ & )$-0.01934^{* * *}(0.00424)$ & $-0.00170(0.00404)$ & $-0.00705^{*}(0.00360)$ \\
\hline $\begin{array}{l}\text { Constant } \\
\text { Statistics }\end{array}$ & $-41.31551^{* *}(13.18254)$ & $-20.82165^{* * * *}(3.97306)$ & $-14.64374^{* * t}(3.07511)$ & $-17.13479^{* 3 * *}(2.25335)$ & ) $-21.95326^{* * *}(2.71178)$ & $-14.00462^{* * *}(1.00244)$ & $-5.43296^{* t *}(0.94460)$ & $-7.24257^{* * *}(0.84294)$ \\
\hline Log likelihood & -88.414 & -156.930 & -166.307 & -179.426 & -170.000 & -324.692 & -375.277 & -387.977 \\
\hline AIC & 188.828 & 325.859 & 344.613 & 370.853 & 352.000 & 661.385 & 762.554 & 787.953 \\
\hline BIC & 201.086 & 338.118 & 356.872 & 383.111 & 364.258 & 673.643 & 774.813 & 800.212 \\
\hline Observations & 57 & 57 & 57 & 57 & 57 & 57 & 57 & 57 \\
\hline
\end{tabular}

${ }^{*} p \leq 0.05$.

$" p \leq 0.01$. 


\section{References}

Beer Institute, 2009. Annual Statistical Abstracts of Brewers Almanac http://www.beerinstitute.org/statistics.asp?bid=200 (accessed 12.01.2009).

Benson, B.L., Rasmussen, D.W., Mast, B.D., 1999. Deterring drunk driving fatalities an economics of crime perspective. International Review of Law and Economics 19 (2), 205.

Berger, D.E., Snortum, J.R., 1986. A structural model of drinking and driving: alcohol consumption, social norms, and moral commitments. Criminology 24 (1), 139-153.

Catalano, R., Dooley, D., Wilson, G., Hough, R., 1993. Job loss and alcohol abuse: a test using data from the epidemiologic catchment area project. Journal of Health and Social Behavior 34 (3), 215-225.

Currie, G., Phung, J., 2007. Transit ridership, auto gas prices, and world events: new drivers of change? Transportation Research Record 1992, 3-10.

Currie, G., Phung, J., 2008. Understanding links between transit ridership and gasoline prices: evidence from the United States and Australia. Transportation Research Record 2063, 133-142.

Dahl, C.A., 1979. Consumer adjustment to a gasoline tax. Review of Economics and Statistics 61 (3), 427-432.

Dang, J.N., 2008. Statistical Analysis of Alcohol-Related Driving Trends, 1982-2005. National Highway Traffic Safety Administration, Washington, DC.

Dee, T.S., 2001. Alcohol abuse and economic conditions: evidence from repeated cross-sections of individual-level data. Health Economics 10 (3), 257-270.

Ettner, S.L., 1997. Measuring the human cost of a weak economy: does employment lead to alcohol abuse? Social Science and Medicine 44 (2), 251.

Evan, W.N., Graham, J.D., 1991. Risk reduction or risk compensation? The case of mandatory safety-belt use laws. Journal of Risk and Uncertainty 4, 61-73.

$\mathrm{Fu}, \mathrm{H}$., 2008. Identifying repeat DUI crash factors using state crash records. Accident Analysis and Prevention 40 (6), 2037-2042.

Goodwin, P., Dargay, J., Hanly, M., 2004. Elasticities of road traffic and fuel consumption with respect to price and income: a review. Transport Reviews 24 (3), 275-292.

Grabowski, D.C., Morrisey, M.A., 2006. Do higher gasoline taxes save lives? Economics Letters 90 (1), 51-55.

Grabowski, D.C., Morrisey, M.A., 2004. Gasoline prices and motor vehicle fatalities. Journal of Policy Analysis and Management 22 (3), 19.

Haire, A.R., Machemehl, R.B., 2007. Impact of rising fuel prices on U.S. transit ridership. Transportation Research Record 1992, 11-19.

Kenkel, D.S., 1993. Drinking, driving, and deterrence: the effectiveness and social costs of alternative policies. Journal of Law and Economics 36 (2), 877-913.

Kim, K., Nitz, L., Richardson, J., Li, L., 1995. Personal and behavioral predictors of automobile crash and injury severity. Accident Analysis and Prevention 27 (4), 469-481.

Leigh, J.P., Geraghty, E.M., 2008. High gasoline prices and mortality from motor vehicle crashes and air pollution. Journal of Occupational and Environmental Medicine 50 (3), 249-254.

Leigh, J.P., Wilkinson, J.T., Portney, P.R., 1991. The effect of gasoline taxes on highway fatalities. Journal of Policy Analysis and Management 10 (3), 474-481.

Long, J.S., 1997. Regression Models for Categorical and Limited Dependent Variables. Sage Publications, Thousand Oaks, CA.
Mayhew, D.R., Ferguson, S.A., Desmond, K.J., Simpson, H.M., 2003. Trends in fatal crashes involving female drivers, 1975-1998. Accident Analysis and Prevention 35 (3), 407-415.

Meyer, M.D., 2004. Women's issues in transportation: policy and planning. In: Conference Proceedings of Women's Issues in Transportation, vol. 1, Chicago, 18-20 November, pp. 51-58.

Nelson, J.P., 1997. Economic and demographic factors in U.S. Alcohol demand: a growth-accounting analysis. Empirical Economics 22 (1), 83-102.

NHTSA, 2009. Traffic Safety Facts 2008. Washington, DC.

Noland, R.B., 2005. Fuel economy and traffic fatalities: multivariate analysis of international data. Energy Policy 33 (17), 2183-2190.

Pearlin, L.I., Radabaugh, C.W., 1976. Economic strains and the coping functions of alcohol. American Journal of Sociology 82 (3), 652-663.

Peirce, R.S., Frone, M.R., Russell, M., Cooper, M.L., 1994. Relationship of financial strain and psychosocial resources to alcohol use and abuse: the mediating role of negative affect and drinking motives. Journal of Health and Social Behavior 35 (4), 291-1291.

Robertson, A.A., Gardner, S., Xu, X.H., Costello, H., 2009. The impact of remedial intervention on 3-year recidivism among first-time DUI offenders in Mississippi. Accident Analysis and Prevention 41 (5), 1080-1086.

Roudsari, B., Ramisetty-Mikler, S., Rodriguez, L.A., 2009. Ethnicity, age, and trends in alcohol-related driver fatalities in the United States. Traffic Injury Prevention 10 (5), 410-414.

Ruhm, C.J., 1995. Economic conditions and alcohol problems. Journal of Health Economics 14 (5), 583-603.

Ruhm, C.J., 1996. Alcohol policies and highway vehicle fatalities. Journal of Health Economics 15 (4), 435-454.

Ruhm, C.J., Black, W.E., 2002. Does drinking really decrease in bad times? Journal of Health Economics 21 (4), 659-678.

Schwilke, E.W., Dos Santos, M.I.S., Logan, B.K., 2006. Changing patterns of drug and alcohol use in fatally injured drivers in Washington state. Journal of Forensic Sciences 51 (5), 1191-1198.

Sloan, F.A., Reilly, B.A., Schenzler, C., 1995. Effects of tort liability and insurance on heavy drinking and drinking and driving. Journal of Law and Economics 38 (1), 49-77.

U.S. Bureau of Census, 2010. State and County QuickFacts. http://quickfacts. census.gov/qfd/states/28000.html (accessed 6.06.2010).

U.S. Bureau of Labor Statistics, 2009. Local Area Unemployment Statistics. http://data.bls.gov/PDQ/servlet/SurveyOutputServlet?data_tool=latest_numbers \&series_id=LASST28000003 (accessed 24.06.2009).

U.S. Congressional Budget Office, 2008. Effects of Gasoline Prices on Driving Behavior and Vehicle Markets. Washington, DC.

Wilkinson, J.T., 1987. Reducing drunken driving: which policies are most effective? Southern Economic Journal 54 (2), 322.

Wilson, F.A., Stimpson, J.P., Hilsenrath, P.E., 2009. Gasoline prices and their relationship to rising motorcycle fatalities, 1990-2007. American Journal of Public Health 99 (10), 1753-1758.

Young, D.J., Bielinska-Kwapisz, A., 2006. Alcohol prices, consumption, and traffic fatalities. Southern Economic Journal 72 (3), 690-703. 